\title{
Evaluation of the Strategic Factors of the Management of Protected Areas Using SWOT Analysis-Case Study: Bashgol Protected Area-Qazvin Province
}

\author{
Siavash Rezazadeh ${ }^{*}$, Ali Jahani' ${ }^{1}$, Majid Makhdoum², Hamid Goshtasb Meigooni ${ }^{1}$ \\ ${ }^{1}$ Department of Natural Environment and Biodiversity, Faculty of Environment, University of Environment, Karaj, Iran \\ ${ }^{2}$ Department of Forestry and Forest Economic, Faculty of Natural Resources, University College of Agriculture and Natural \\ Resources, University of Tehran, Karaj, Iran \\ Email:*Rezazadeh_msr@yahoo.com
}

How to cite this paper: Rezazadeh, S., Jahani, A., Makhdoum, M. and Meigooni, H.G. (2017) Evaluation of the Strategic Factors of the Management of Protected Areas Using SWOT Analysis-Case Study: Bashgol Protected Area-Qazvin Province. Open Journal of Ecology, 7, 55-68. http://dx.doi.org/10.4236/oje.2017.71005

Received: October 6, 2016

Accepted: January 20, 2017

Published: January 23, 2017

Copyright $\odot 2017$ by authors and Scientific Research Publishing Inc. This work is licensed under the Creative Commons Attribution International License (CC BY 4.0).

http://creativecommons.org/licenses/by/4.0/ c) (i) Open Access

\begin{abstract}
The majority of Iranian protected areas are being affected by human activities. Such areas demand continuous monitoring into account due to quality loss problem. This study identifies the weaknesses and strengths as well as opportunities and threats of Bashgol protected area and analyzes them using SWOT matrix in order to provide an efficient managerial strategy. Following the identification of factors, experts' opinion was collected using questionnaire. Then, the factors were scored based on IFE (Internal Factors Evaluation) and EFE (External Factors Evaluation) tables and were weighted using AHP and EXPERT CHOICE. Totally, 16 strengths and opportunities were determined as the advantages of this area and 22 weaknesses and threats were identified as the limitations and straits. The final scores of IFE and EFE were 2.468 and 2.261 , respectively and both are below 2.5 indicating that the area is in defensive state. According to quantitative strategic planning matrix (QSPM), "attracting required credits for the completely implementation of the comprehensive management plan of the area" was determined as the most important strategy (score $=6.365)$.
\end{abstract}

Keywords

Assessment, Bashgol Protected Area, Strategic Factors, SWOT

\section{Introduction}

The environment has a number of limitations preventing it from unlimitedly development even by the aid of the best conceivable technologies [1]. Failure in 
taking such limitations into account in the process of economic development will result in the environmental depletion [2]. Emphasizing the dependencies between conservation and development, sustainable development phrase was first put forward in the global strategy for the conservation of environment in order to solve various environmental problems [3]. A society which seeks for sustainable development should first have a complete understanding of its environment and then try to protect it relying on strategic planning [4]. Strategic planning is constituted by four essential components: environmental investigation, strategy development, strategy implementation and control and assessment [5]. There are different strategic planning models and all of them have been inspired by SWOT analytical model (Strength, Weakness, Opportunity and threat) [6]. This technique was first introduced in 1960s by Albert Humphery during his research project in Stanford University using data of 500 companies [7] [8]. SWOT matrix has attracted attention as an efficient instrument for the strategic planning of environment management [9] [10]. This technique provides a systematic analysis instrument for identifying internal and external factors and selecting the best fit strategy establishing the best concordance between the factors [11].

Today, the implementation of protection plans for species and eco-systems has been limited to given areas which are called protected areas. The majority of such areas are extremely affected by human activities due to chaotic development as well as socio-economic condition of local communities. This has reduced the quality of such areas and they need continuous monitoring. Currently, many plans are put forward to enhance the application of protected areas following sustainable development. Furthermore, attempts are made to abandon the concept of nature islands from such areas, unlike traditional beliefs, and exhibit their actual efficiency and strength [12]. Iranian protected areas are managed with the mere aim of protection while other targets can be taken into account that not only conflict with conservation practices but also may be aligned with conservation, revival and improvement practices for such areas. Considering the importance and vital role of protected areas in different educational, research, recreation and tourism dimensions, conducting research studies in the areas, including strategic planning and management practices, is of high importance.

No study has been ever carried out in Bashgol protected area with the subject of "the evaluation of the strategic factors of management". Therefore, it is necessary to monitor and evaluate the influential factors of the area management in order to conserve the sustainability and biodiversity of the area on the one hand and to prevent damages and to reduce the negative effects of human activities on the other hand. To this end, formulating efficient solutions, which are compatible with socio-cultural, economic, environmental and protection condition of the area [13], and accurate execution of them by related authorized organizations play a vital role in mitigating the negative effects of human-environment conflicts and achieving managerial targets. Such targets can be achieved by identifying influential internal and external factors and developing efficient strategies 
using SWOT analysis [14]. There are different studies on this field. In studies such as, present a strategic environmental plan for Mond protected area [15], codifying the managerial development strategies to protect Miankaleh wetland [16], assessment of ecotourism development plan in Sangobai wetland [17], evaluation of ecological and tourism development potentials of Gahar Lake [18] and assessment of recreation opportunities in Miankaleh wildlife refuge used SWOT technique [19]. Analytical SWOT matrix, was also used for analyzing the conventional techniques for impact assessment in India [20] and studying the managerial challenges of tourism development in southern coasts of Khazar Sea [21]. In other studies, analyzing the tourism infrastructures in Uremia eco-tourist [22] and codification of eco-tourism sustainable development strategic plan in Varjin protected area [23] were done using SWOT technique and a combination of SWOT, IEM and QSPM respectively.

The aim of this study is to analyze and evaluate current management condition of the studied area and to present the best fit managerial strategy using SWOT and QSPM in order to improve current protection condition, support strengths and utilize available opportunities.

\section{Materials and Methods}

\subsection{Introduction of the Studied Area}

With an area of 24399 hectares, Bashgol protected area is located $3 \mathrm{~km}$ from the northwest of Takestan between Takestan and Abhar cities in the southern skirts of the Central Alborz Mountains and lies inside $49^{\circ} 28^{\prime}$ to $49^{\circ} 43^{\prime}$ east longitude and $36^{\circ} 03^{\prime}$ to $36^{\circ} 14^{\prime}$ north latitude (Figure 1 ). As the only protected area of Qazvin province, this area is the only deer habitat, with little population, and is the easternmost region in Iran in which Armenian mouflons have been dispersed.

\subsection{Method of Study}

This study uses qualitative and quantitative strategic analysis technique. This so called SWOT technique is the direct outcome of Harvard Business School model. This technique is actually the best fit strategy for organizations. SWOT analysis is a general instrument used to identify internal weaknesses and strengths and external opportunities and threats to which an organization may encounter. The most important internal and external environmental factors with probable influence on the future of an activity are introduced as strategic factors which are summarized and listed in SWOT analysis [24]. It can be argued, in brief, that this technique is an instrument for status assessment and strategy formulation which are practiced through the following steps: a) recognition and classification of internal weaknesses and strengths of a system, b) recognition and classification of opportunities and threats, available in the external environment of a system, c) completion of SWOT matrix and d) developing different strategies for directing the system in future. SWOT is implemented in the following steps. 


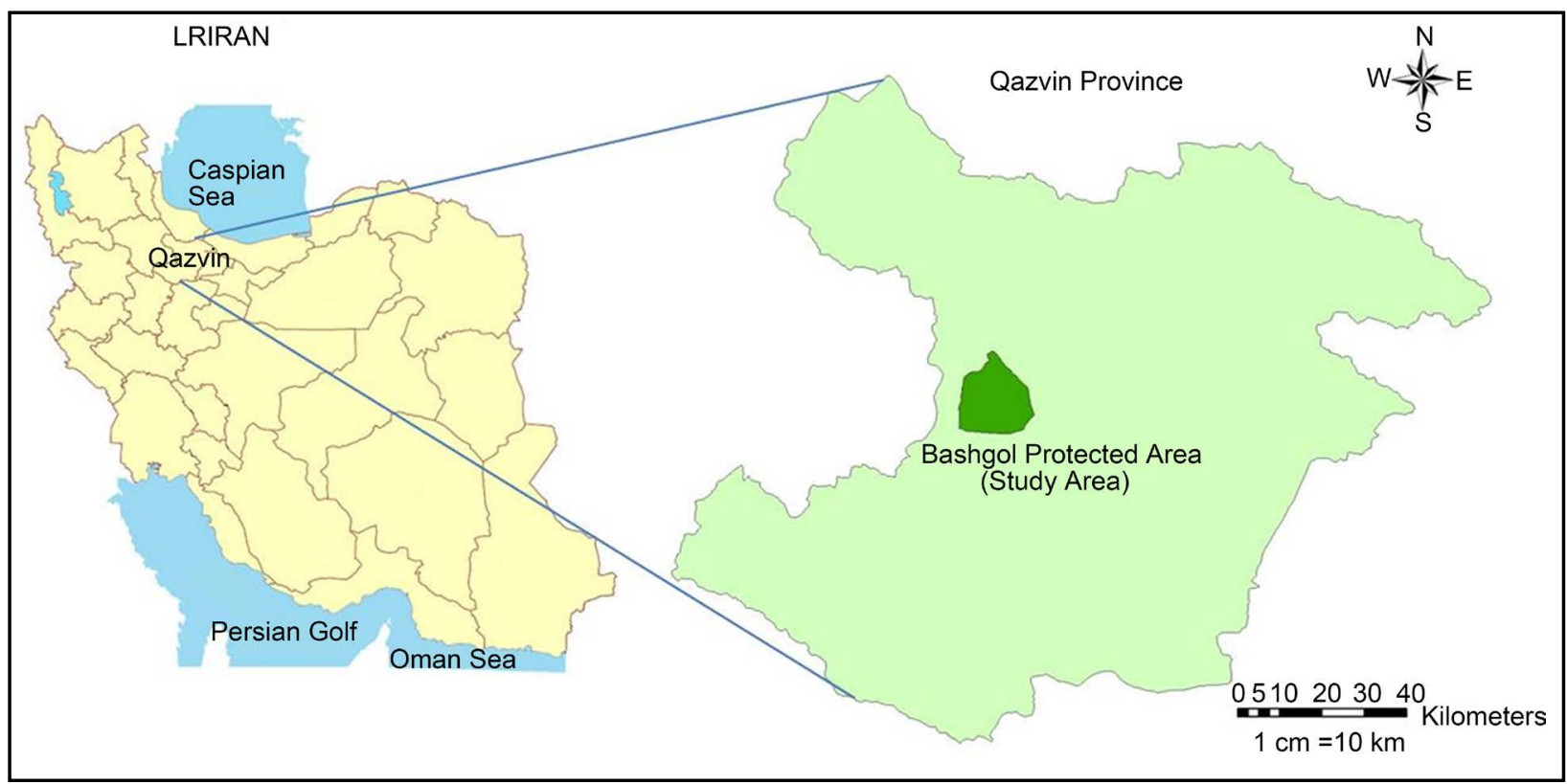

(a)

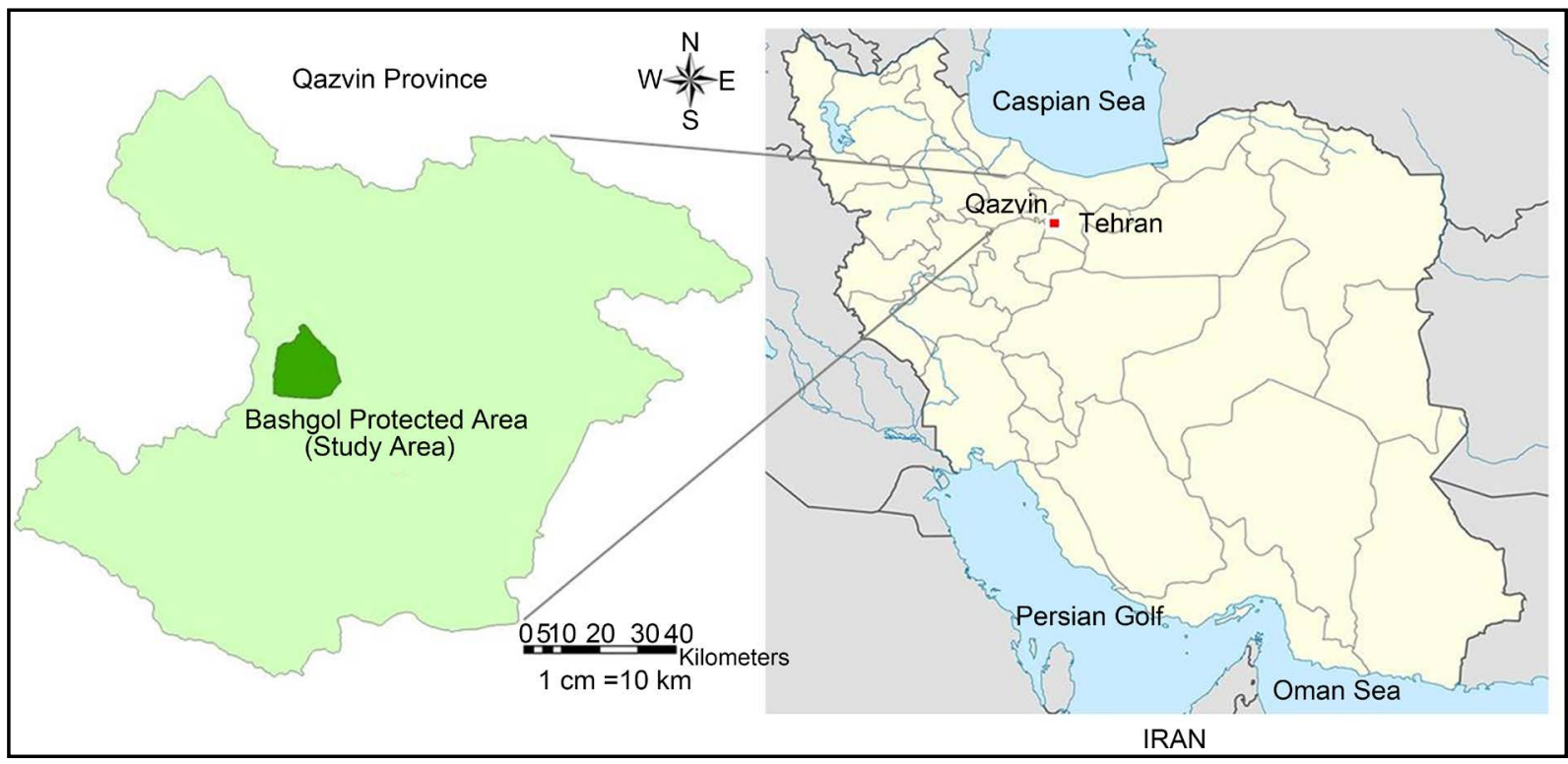

(b)

Figure 1. Location of the study area in Qazvin Province, Iran.

directing the system in future. SWOT is implemented in the following steps.

\subsection{Selection of Population}

This study adopted questionnaire, interview, desk studies and field studies as study tools. A total number of 36 conservative officers and associated specialists, retired staffs and managers of staff offices and provinces who are currently being engaged, or were being engaged, in the management activities of Bashgol protected area were selected as our population and were considered as the experts. The inclusion criteria for the expert population of this study were 1) at least 3 years record in activities related to Bashgol protected area, 2) possessing mini- 
mum related university degree, 3) being specialist in the executive, administrative or scientific affairs of the area and 4) awareness of the constraints and problems as well as the opportunities and threats of the area.

\subsection{Formation of IFE and EFE Matrix}

IFE matrix is an instrument for assessing internal factors (weaknesses and strengths) [25] EFE matrix is an instrument for analyzing external opportunities and threats [26]. First, the strengths and weaknesses were listed and a weight between 0 (not important) to 1 (very important) was allocated to every factor. The sum of the allocated weights should be 1. EXPERT CHOICE was used to easily calculate the relative weight of criteria and items. To this end, AHP structure was formed and the scores of criteria inserted in the rows and columns of the priority matrices of the software were recorded. In this way, the relative weight of criteria to each other and the overall weight of items were calculated.

1) A score between 1 to 4 was allocated to each factor (score 1 stands for strongly weakness, score 2 stands for low weakness, score 3 stands for strength, score 4 stands for strongly strength)

2) To determine the final score of each factor, the coefficient of each factor was multiplied by the score of that factor.

3) The sum of final scores of each factor was calculated in order to determine the overall score of the factor.

Mean score $<2.5$ means that the organization is weak in internal factors while mean score $>2.5$ means that the organization is strong.

To form EFE matrix, opportunities and weaknesses were first listed and a weight between 0 (not important) to 1 (very important) was allocated to every factor. The sum of allocated weights should be 1 .

Again, a score from 1 to 4 was allocated to the factors and the coefficient of each factor was multiplied by corresponding score to determine the final score of the factor. The sum of final scores of every factor was calculated in order to determine the overall score of the factor. Mean score $<2.5$ means that the organization is threatened by external factors threat while mean score $>2.5$ means that the organization has opportunities.

\subsection{Formation of SWOT Matrix}

SWOT can serve as a basis for managers' and specialists' decisions and the determination of objectives [27]. Considering internal and external factors governing an organization it can provide a fit basis for formulating strategy [28]. SWOT can be considered as a step of a process accelerating the achievement of final target by formulating necessary policies for balancing internal and external factors. SPAE (Strategic Position and Action Evaluation) is an instrument used to analyze internal and external factors at the same time.

\subsection{Formulating Strategies in SWOT Matrix}

SWOT matrix makes it possible to formulate four different alternatives or strat- 
egies. In practice, some strategies overlap with each other or are coordinately executed at the same time. SWOT analysis systematically analyzes pre-identified weaknesses, strengths, opportunities and threats and gives situation-specific strategies. In SWOT, when each weakness, strength, opportunity and threat factor, identified in the previous step, are specified they are listed and inserted in relevant cells. Then, considered strategies are extracted in terms of the order of weights from the intersection of the cells. Therefore, this matrix will always give four classes of strategies: ST, WT, WO and SO.

\subsection{Quantitative Strategic Planning Matrix (QSPM)}

This matrix uses data obtained in different steps of strategic management and planning. Similar to other strategic approaches, it demands accurate judgment, proficiency and awareness. QSPM is used to evaluate the applicability and sustainability of suggested approaches when they expose to available circumferential conditions. In this matrix, if a strategy fails to tolerate internal and external conditions, it should be excluded from prioritizable strategies. The first column of this matrix enlists all threats and opportunities as well as internal strategic factors, including all weaknesses and strength. In the second column, the weighted score of each strategic factor, which have exactly been derived from IFE and EFE matrices, are inserted. The next columns include different strategies derived from SWOT matrix including WO, ST, WT and ST strategies. Each strategy column is divided into two sub-columns: AS and ATS. In AS sub-column, attractiveness score is allocated in the following manner. Every strategic factor is assessed via the considered strategy and is scored. The process of allocating attractiveness score should answer this question that: does this factor affect the selection of the considered strategy? If yes, the attractiveness score should be allocated in a special way considering the relative attractiveness of a strategy to another strategy. Attractiveness scores are as follows:

$1=$ no attractive, $2=$ attractive to some extent, $3=$ attractive to an acceptable level, $4=$ strongly attractive.

If the answer is no, this will indicate that the strategic factor does not affect the strategy item and the attractiveness score of that strategy will be 1 in the strategic factor row. The scores inserted in the second column are multiplied by the attractiveness score and total attractiveness score (TAS) is obtained. TAS indicates the relative attractiveness of each factor to the considered strategy. The sum of TAS scores is calculated at the bottom row. This is the priority score of the strategy. In this way, different strategic alternatives of an organization are prioritized using numerical values and become comparable.

\section{Results}

According to results, in Bashgol protected area, 8 internal strengths versus 10 internal weaknesses and 6 external opportunities versus 12 external threats can be recognized and studied. Totally, there are 16 strengths and opportunities as the advantages of this area and 22 weaknesses and threats as the restraints and 
limitations of it. According to IFE assessment, the existence of sufficient springs, water resources and troughs, constructed by the Environment Organization inside the area, diverse and rich plant and animal life and existence of dry farmed wheat fields in the southern regions of the area (deer habitat), which attract and conserve deer population, are the most important strengths of the area with scores $0.276,0.244$ and 0.232 , respectively. In contrast, stockbreeding activities and exploiting the exception lands of the area, lack of a secure migration corridor for animal species outside the area and lack of a plan for participatory management of local communities for conservation of the area are the most important weaknesses of the area with scores $0.136,0.126$ and 0.122 , respectively (Table 1).

Table 1. Internal Factors Evaluation (IFE) matrix.

\begin{tabular}{|c|c|c|c|c|c|}
\hline \multicolumn{3}{|r|}{ Internal strategic factors } & Normalized & Current status & Weighted \\
\hline \multicolumn{6}{|c|}{ Strengths } \\
\hline 1 & S1 & $\begin{array}{l}\text { Sufficient springs, water resources and troughs, constructed by the } \\
\text { Environment Organization inside the area }\end{array}$ & 0.069 & 4 & 0.276 \\
\hline 2 & S2 & Employing modern conservation equipment including monitoring cameras & 0.059 & 3 & 0.204 \\
\hline 3 & S3 & $\begin{array}{l}\text { Qazvin Environment Conservation Organization attention to the } \\
\text { protection of the area }\end{array}$ & 0.055 & 4 & 0.220 \\
\hline 4 & S4 & $\begin{array}{c}\text { Awareness of the area residents of wildlife, regulations and the limitations } \\
\text { and conditions of the area }\end{array}$ & 0.048 & 4 & 0.192 \\
\hline 5 & S5 & $\begin{array}{c}\text { Dry farmed wheat fields in the southern regions of the area (deer habitat) } \\
\text { which attract and conserve deer population }\end{array}$ & 0.058 & 4 & 0.232 \\
\hline 6 & S6 & Benefiting from diverse and rich plant and animal life & 0.061 & 4 & 0.0244 \\
\hline 7 & S7 & Negative growth of rural population inside the area and abandoned villages & 0.058 & 3 & 0.174 \\
\hline 8 & S8 & $\begin{array}{l}\text { Eco-tourism attractiveness potential thanks to original intact scenes and } \\
\text { ancient and cultural works }\end{array}$ & 0.041 & 3 & 0.123 \\
\hline \multicolumn{6}{|c|}{ weaknesses } \\
\hline 9 & W1 & Stockbreeding activities and exploiting the exception lands of the area & 0.068 & 2 & 0.136 \\
\hline 10 & W2 & No precise boundaries between exceptions and national lands & 0.046 & 1 & 0.046 \\
\hline 11 & W3 & $\begin{array}{c}\text { Lack of a plan for participatory management of local communities for } \\
\text { conservation of the area }\end{array}$ & 0.061 & 2 & 0.122 \\
\hline 12 & W4 & $\begin{array}{l}\text { Human force shortage with respect to the area of the protected area } \\
\text { considering global standards }\end{array}$ & 0.053 & 2 & 0.106 \\
\hline 13 & W5 & $\begin{array}{l}\text { Scofflaws violating environmental rules including hunters, herdsmen and } \\
\text { native users }\end{array}$ & 0.054 & 1 & 0.054 \\
\hline 14 & W6 & $\begin{array}{l}\text { Difference between the condition and type of employment of conservation } \\
\text { officer and factors affecting the area protection }\end{array}$ & 0.057 & 1 & 0.057 \\
\hline 15 & W7 & $\begin{array}{l}\text { Insufficient conservation equipment, vehicles and infrastructure } \\
\text { installations }\end{array}$ & 0.052 & 1 & 0.052 \\
\hline 16 & W8 & Lack of facilities for admission and hosting tourists such as tourist centers & 0.039 & 1 & 0.039 \\
\hline 17 & W9 & Lack of safe migration corridors for animal species outside the area & 0.063 & 2 & 0.126 \\
\hline 18 & W10 & Lack of adequate motivated conservative officers in recent years & 0.065 & 1 & 0.065 \\
\hline & - & Total & 1 & -- & 2.468 \\
\hline \multicolumn{6}{|c|}{$\mathrm{IFE}=2.468$} \\
\hline
\end{tabular}


According to EFE, formulating and approval of the master plan (feasibility studies and detailed plan) for the management of Bashgol protected area, conceiving the judiciary system of Qazvin Province to cooperate in decisive actions against offenders and increased penalties against violating rules associated with hunting of animal species are the most important opportunities of this protected area with scores of $0.3,0.195$ and 0.184 , respectively. In contrast, experts and advisers believe that excessive grazing and no observation of grazing rules in the postures of this area, main roads around the area especially Qazvin-Zanjan freeway and widening Ziaabad-Nikueyie road and recent climate change impacts including drought, heavy snow, extreme freeze are the most important threats of the area with scores $0.14,0.13$ and 0.126 , respectively (Table 2 ).

Table 2. External Factors Evaluation (EFE) matrix.

\begin{tabular}{|c|c|c|c|c|c|}
\hline & & External strategic factors & $\begin{array}{l}\text { Normalized } \\
\text { weight }\end{array}$ & $\begin{array}{l}\text { Current status } \\
\text { score }\end{array}$ & $\begin{array}{l}\text { Weighted } \\
\text { score }\end{array}$ \\
\hline \multicolumn{6}{|c|}{ Opportunities } \\
\hline 1 & $\mathrm{O} 1$ & $\begin{array}{l}\text { formulating and approving the master plan (feasibility study and detailed } \\
\text { plan) for the management of Bashgol protected area }\end{array}$ & 0.075 & 4 & 0.300 \\
\hline 2 & $\mathrm{O} 2$ & $\begin{array}{l}\text { conducting various collegiate studies about conservation and management of } \\
\text { species and habitats in Bashgol protected area }\end{array}$ & 0.058 & 3 & 0.174 \\
\hline 3 & $\mathrm{O} 3$ & $\begin{array}{l}\text { increased penalties against violating rules associated with hunting of animal } \\
\text { species }\end{array}$ & 0.046 & 4 & 0.184 \\
\hline 4 & $\mathrm{O} 4$ & $\begin{array}{l}\text { conceiving the judiciary system of Qazvin Province to cooperate in decisive } \\
\text { actions against offenders }\end{array}$ & 0.065 & 3 & 0.195 \\
\hline 5 & $\mathrm{O} 5$ & $\begin{array}{c}\text { proper position of the area in terms of attracting and developing sustainable } \\
\text { tourism }\end{array}$ & 0.061 & 3 & 0.183 \\
\hline 6 & O6 & $\begin{array}{l}\text { the role of the reputability of the area in attracting public opinion and } \\
\text { authorities' supports }\end{array}$ & 0.057 & 3 & 0.171 \\
\hline \multicolumn{6}{|c|}{ Threats } \\
\hline 9 & $\mathrm{~T} 1$ & $\begin{array}{l}\text { climate change impacts including recent drought, heavy snow and extreme } \\
\text { freeze }\end{array}$ & 0.063 & 2 & 0.126 \\
\hline 10 & $\mathrm{~T} 2$ & $\begin{array}{l}\text { excessive grazing and no observation of grazing rules in the postures of this } \\
\text { area }\end{array}$ & 0.070 & 2 & 0.140 \\
\hline 11 & T3 & $\begin{array}{l}\text { the risk of prevalence and transmission of diseases between livestock and } \\
\text { wild animals in the area }\end{array}$ & 0.042 & 1 & 0.042 \\
\hline 12 & $\mathrm{~T} 4$ & change of land use and development of dry farming in the area boundaries & 0.054 & 1 & 0.054 \\
\hline 13 & T5 & $\begin{array}{l}\text { unauthorized hunters and the dominancy of their equipment on the } \\
\text { equipment of the conservative officers }\end{array}$ & 0.048 & 2 & 0.096 \\
\hline 14 & T6 & $\begin{array}{l}\text { constructional activities including road construction, civil installations and } \\
\text { development of power and energy transmission lines }\end{array}$ & 0.061 & 2 & 0.122 \\
\hline 16 & $\mathrm{~T} 8$ & $\begin{array}{l}\text { economic and life status of the area natives and related factors affected by } \\
\text { them }\end{array}$ & 0.042 & 1 & 0.042 \\
\hline 17 & T9 & Serious presence of free-ranging and sheep dogs in the area & 0.056 & 2 & 0.112 \\
\hline 18 & $\mathrm{~T} 10$ & $\begin{array}{c}\text { main roads around the area, especially Qazvin-Zanjan freeway and widening } \\
\text { Ziaabd-Nikuye road }\end{array}$ & 0.065 & 2 & 0.130 \\
\hline 19 & $\mathrm{~T} 11$ & fires and potential of causing fires in grass postures and dry farms & 0.046 & 1 & 0.046 \\
\hline 20 & $\mathrm{~T} 12$ & mine exploitation activities & 0.038 & 1 & 0.038 \\
\hline & - & Total & 1 & -- & 2.261 \\
\hline \multicolumn{6}{|c|}{$\mathrm{IFE}=2.261$} \\
\hline
\end{tabular}


The score derived for the overall sum of IFE is 2.468, which is below 2.5. This implies that currently the number of weaknesses in Bashgol protected area is higher than that of strengths. In addition, the overall sum of EFE is 2.261. Again, this is below 2.5 implying that the number of coming threats is higher than the number of opportunities.

Analyzing the current environmental management of Bashgol protected area leads to the resultant of IFE and EFE final scores i.e. IE matrix. In this matrix, IFE constitutes $\mathrm{X}$-axis and EFE constitutes $\mathrm{Y}$-axis. As it is seen in the figure, the intersection of these axes is located at defensive zone (Figure 2).

According to Figure 2, SWOT analysis results in 5 aggressive strategies, 4 conservative strategies, 4 competitive strategies and 4 defensive strategies (Figure 3). Since this study prefers WT strategies, the four defensive strategies were analyzed quantitatively. A) Formulating and implementing HRM plan aimed at motivating conservative officers, B) Attracting necessary credits for complete implementation of the comprehensive management plan of the area, C) Formulating and implementing the plan for participatory management of local communities in protecting the area and D) expansion of the contribution of scientific and research centers to the enhancement of conservation standards.

The results of QSPM reveal that among formulated strategies the maximum attractiveness belongs to the strategy of "attracting required credits for completely implementation of the comprehensive plan for the area management" (Table 3).

\section{Discussion and Conclusion}

Considering the method and objective adopted by this study to analyze the current conservation management of Bashgol protected area, the number of strengths and opportunities is lower than that of weaknesses and threats. The

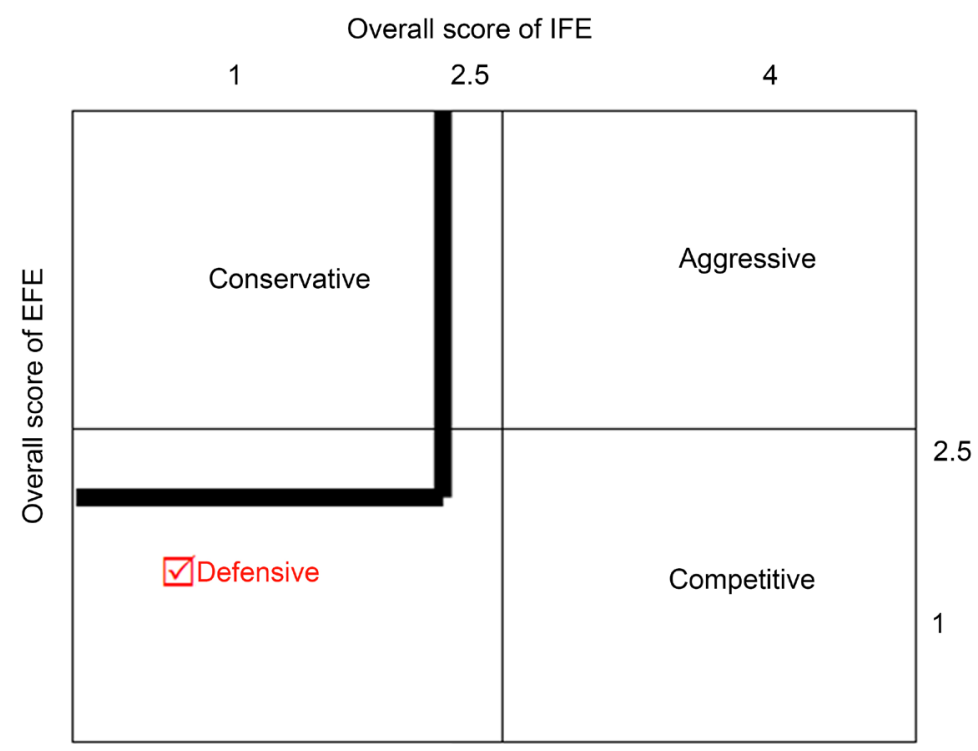

Figure 2. Current status of the environmental management of the studied area (IFE and EFE). Note: Based on this figure, defensive strategy matrix should be selected. 
Conservative strategies (WO)

1. Promotion of protection standards and indices in the area

2. Employing financial, physical and human capabilities

3. Employing modern technologies of conservation approaches with the purpose of the suatainable development of the area

4. Adopting the strategy of training local communities and exploiters

Defensive strategies (WT)

1. Formulating and executing HRM plan aimed at motivating conservative oficers

2. Attracting required credits for implementing the comprehensive management plan for the area

3. Formulating and executing the plan of participatory management of local communities for protecting the area

4. Attracting wide participation of scientific and research centers dor enhancing conservation standards
Aggressive strategies (SO)

1. Enhancing the managemnet level of Bashgol protected area to national park aimed at the development of the area

2. Developing ecotourism in the area via the participation of local communities

3. Formulating the strategic plan for the environmental risks of the area

4. Equipping the area infrastructure for promotion of conservation

5. Purchasing common laws of herdmen and freeing exceptions of the area

Competitive strategies (ST)

1. Securing the migration corridor of ewe and ram by surrendering it to Bashgol protected area

2. Applying legal restrictions and pressures for limiting the development of roads

3. Preparing cadastral map and determining national lands and exceptions boundaries

4. Preventing any development activity in the area

Figure 3. Fourfold strategies of SWOT matrix.

highest score (6.365) belongs to the strategy of "attracting required credits for the completely implementation of the comprehensive plan for the area management" and it was introduced as the most important strategy followed by "formulating and executing the plan for participatory management of local communities" with a score of 6.021. In a similar study, three strategies were prioritized based on their attraction scores for Mond protected area and the strategy of using conservative approach got the highest score [14] Another study shows that the sustainable exploitation of wetlands should be based on their potentials and capabilities and to repair their abnormal situation and avoid any interference, the wetlands should be supported and protected [17] The results of a research on the managerial challenges in Miankaleh showed that the participation of natives can assure the conservation of the environment and also promote their economic condition [22] The study of codification of eco-tourism sustainable development strategic plan in Varjin protected area indicated that the mentioned area is in IE situation and based on prioritizing the strategies resulted in quantitative strategic planning matrix (QSPM), of "allocating more credits for management and protection of the area and conducting research projects" ranked the first with a score of 12.895 [24], which agrees with our study. In accordance with study on environmental management of Hashilan wetland, it 
Table 3. Quantitative Strategic Planning (QSPM) matrix.

\begin{tabular}{|c|c|c|c|c|c|c|c|c|c|c|}
\hline \multirow{2}{*}{\multicolumn{2}{|c|}{ Main factors }} & \multirow{2}{*}{$\begin{array}{c}\text { weight } \\
\text { coefficient }\end{array}$} & \multicolumn{2}{|c|}{$1^{\text {st }}$ strategy } & \multicolumn{2}{|c|}{$2^{\text {nd }}$ strategy } & \multicolumn{2}{|c|}{$3^{\text {rd }}$ strategy } & \multicolumn{2}{|c|}{$4^{\text {th }}$ strategy } \\
\hline & & & AS & TAS & AS & TAS & AS & TAS & AS & TAS \\
\hline \multirow{8}{*}{ 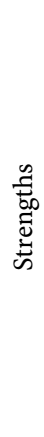 } & S1 & 0.069 & 1 & 0.069 & 3 & 0.207 & 1 & 0.069 & 1 & 0.069 \\
\hline & S2 & 0.052 & 3 & 0.159 & 4 & 0.208 & 3 & 0.156 & 3 & 0.156 \\
\hline & S3 & 0.055 & 4 & 0.220 & 4 & 0.220 & 4 & 0.220 & 4 & 0.220 \\
\hline & S4 & 0.048 & 1 & 0.048 & 3 & 0.144 & 4 & 0.192 & 1 & 0.048 \\
\hline & S5 & 0.058 & 1 & 0.058 & 1 & 0.058 & 3 & 0.116 & 1 & 0.058 \\
\hline & S6 & 0.061 & 3 & 0.183 & 4 & 0.244 & 3 & 0.183 & 4 & 0.244 \\
\hline & S7 & 0.058 & 1 & 0.058 & 2 & 0.108 & 2 & 0.116 & 1 & 0.058 \\
\hline & S8 & 0.041 & 1 & 0.041 & 3 & 0.123 & 4 & 0.164 & 3 & 0.123 \\
\hline \multirow{10}{*}{ 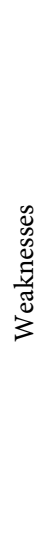 } & $\mathrm{W} 1$ & 0.068 & 1 & 0.068 & 4 & 0.272 & 4 & 0.272 & 2 & 0.136 \\
\hline & $\mathrm{W} 2$ & 0.046 & 1 & 0.046 & 4 & 0.184 & 4 & 0.184 & 2 & 0.092 \\
\hline & W3 & 0.061 & 1 & 0.122 & 4 & 0.244 & 4 & 0.244 & 3 & 0.183 \\
\hline & $\mathrm{W} 4$ & 0.053 & 4 & 0.212 & 4 & 0.212 & 4 & 0.212 & 2 & 0.106 \\
\hline & W5 & 0.054 & 4 & 0.216 & 2 & 0.108 & 4 & 0.216 & 2 & 0.108 \\
\hline & W6 & 0.057 & 4 & 0.228 & 3 & 0.171 & 3 & 0.171 & 1 & 0.057 \\
\hline & W7 & 0.052 & 4 & 0.208 & 4 & 0.208 & 2 & 0.104 & 2 & 0.104 \\
\hline & W8 & 0.039 & 2 & 0.078 & 4 & 0.156 & 3 & 0.117 & 1 & 0.039 \\
\hline & W9 & 0.063 & 2 & 0.126 & 4 & 0.252 & 4 & 0.252 & 3 & 0.189 \\
\hline & W10 & 0.065 & 4 & 0.260 & 3 & 0.195 & 3 & 0.195 & 2 & 0.130 \\
\hline \multirow{6}{*}{ 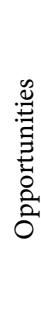 } & $\mathrm{O} 1$ & 0.075 & 3 & 0.225 & 4 & 0.300 & 4 & 0.300 & 4 & 0.300 \\
\hline & $\mathrm{O} 2$ & 0.058 & 3 & 0.174 & 3 & 0.174 & 3 & 0.174 & 4 & 0.232 \\
\hline & $\mathrm{O} 3$ & 0.046 & 1 & 0.046 & 1 & 0.046 & 2 & 0.092 & 1 & 0.046 \\
\hline & $\mathrm{O} 4$ & 0.065 & 2 & 0.130 & 3 & 0.195 & 2 & 0.130 & 1 & 0.065 \\
\hline & $\mathrm{O} 5$ & 0.061 & 1 & 0.061 & 3 & 0.183 & 3 & 0.183 & 3 & 0.183 \\
\hline & O6 & 0.057 & 2 & 0.114 & 4 & 0.228 & 3 & 0.171 & 4 & 0.228 \\
\hline \multirow{12}{*}{ 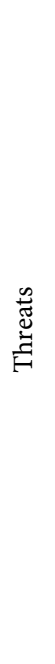 } & $\mathrm{T} 1$ & 0.063 & 1 & 0.063 & 4 & 0.252 & 2 & 0.126 & 3 & 0.189 \\
\hline & $\mathrm{T} 2$ & 0.070 & 1 & 0.070 & 4 & 0.280 & 4 & 0.280 & 3 & 0.210 \\
\hline & T3 & 0.042 & 1 & 0.042 & 3 & 0.126 & 3 & 0.126 & 3 & 0.126 \\
\hline & $\mathrm{T} 4$ & 0.054 & 3 & 0.162 & 4 & 0.216 & 4 & 0.216 & 2 & 0.108 \\
\hline & T5 & 0.048 & 3 & 0.144 & 3 & 0.144 & 3 & 0.144 & 2 & 0.096 \\
\hline & T6 & 0.061 & 2 & 0.122 & 2 & 0.122 & 2 & 0.122 & 1 & 0.061 \\
\hline & $\mathrm{T} 7$ & 0.053 & 4 & 0.212 & 4 & 0.212 & 3 & 0.169 & 4 & 0.212 \\
\hline & T8 & 0.042 & 2 & 0.084 & 3 & 0.126 & 4 & 0.168 & 1 & 0.042 \\
\hline & T9 & 0.056 & 1 & 0.056 & 3 & 0.168 & 3 & 0.168 & 1 & 0.056 \\
\hline & $\mathrm{T} 10$ & 0.065 & 1 & 0.065 & 1 & 0.065 & 1 & 0.065 & 2 & 0.130 \\
\hline & $\mathrm{T} 11$ & 0.046 & 2 & 0.092 & 3 & 0.138 & 3 & 0.138 & 2 & 0.092 \\
\hline & $\mathrm{T} 12$ & 0.038 & 1 & 0.038 & 2 & 0.076 & 2 & 0.076 & 1 & 0.038 \\
\hline \multicolumn{2}{|c|}{ Sum } & & \multicolumn{2}{|c|}{4.297} & \multicolumn{2}{|c|}{66.365} & \multicolumn{2}{|c|}{6.021} & \multicolumn{2}{|c|}{4.525} \\
\hline
\end{tabular}

$\checkmark \quad$ The $2^{\text {nd }}$ strategy is selected. 
is in aggressive strategy and applying the strategy of "the integrated management of the wetland" is the best practice [29].

Optimized management and protection of Bashgol area are of high importance on the one hand and this area is not currently in an ideal situation on the other hand. Furthermore, the strategy of "attracting required credits for completely implementation of the comprehensive plan for the area management" was selected and weaknesses and threats were identified from SWOT and QSPM matrices. Therefore, it is suggested that authorized managers endeavor to plan organizational follow-ups for attracting predicted credits for implementing the comprehensive plan for the area management in order to both compensate weaknesses and eliminate factors threatening the sustainable and essential development of the area.

\section{Acknowledgements}

The authors need to consider their thanks and appreciation for the cooperation and participation of the Director General and the staff of the Department of Environmental Protection in Qazvin Province and the guards of Bashgol protected area express.

\section{References}

[1] Vahhabzade, A. (1998) Conservation of the Earth, a Strategy for Sustainable Life. Jahad Daneshgahi Publication, Mashhad.

[2] Habitat, T.A. (1992) A Methodological Framework of EIA for Urban Development. UN Centre for Human Settlements.

[3] Chamani, A., Makhdoum, M., Jafari, M., Khorasani, N. and Cheraghi, M. (2005) Evaluation of Environmental Impacts of Development in Hamedan Province. Journal of Environmental Studies, 37, 35-44.

[4] Eftekhari, A. and Mahdavi, D. (2006) Rural Tourism Development Approaches Based on SWOT, Case Study: Small Lavasan Village. Humanities Quarterly, 45, $1-31$.

[5] Hussey, D. (2001) Strategy and Planning. Wiley, New York.

[6] Mintzberg, H., Ahlstrand, B. and Lampel, J. (1998) Strategy Safari: A Guided Tour through the Wilds of Strategic Management. Free Press, New York.

[7] Arslan, O. and Er, I.D. (2008) SWOT Analysis for Safer Carriage of Bulk Liquid Chemicals in Tankers. Journal of Hazardous Materials, 154, 901-913. https://doi.org/10.1016/j.psep.2008.06.006

[8] Saaty, R.W. (1987) The Analytic Hierarchy Process and SWOT Analysis What It Is and How It Is Used. Mathematical Modeling, 9, 161-178. https://doi.org/10.1016/0270-0255(87)90473-8

[9] Nikolaou, I.E. and Evangelinos, K.I. (2010) A SWOT Analysis of Environmental Management Practices in Greek Mining and Mineral Industry. Resources Policy, 35, 226-234. https://doi.org/10.1016/j.resourpol.2010.02.002

[10] Diamantopoulou, P. and Voudouris, K. (2008) Optimization of Water Resources Management Using SWOT Analysis: The Case of Zakynthos Island, Ionian Sea, Greece. Environmental Geology, 54, 197-211. https://doi.org/10.1007/s00254-007-0808-5 
[11] Harrison, J. and John, K. (2007) Strategic Management. 4th Edition, Heyat Publications, Iran.

[12] Majnounian, H. (2010) National Parks and Protected Areas, Values and Applicationsm. Environment Organization Publications, Iran.

[13] Diestefano, E. (2005) World Conservation Union on Human-Wildlife Conflict, Human-Wildlife Conflict Worldwide: Collection of Case Studies, Analysis of Management Strategies and Good Practices. FAO, Rome.

[14] Houben, G., Lenie, K. and Vanhoof, K. (1999) A Knowledge-Based SWOT-Analysis System as an Instrument Forstrategic Planning in Small and Medium Sized Enterprises. Decision Support Systems, 26, 125-135. https://doi.org/10.1016/S0167-9236(99)00024-X

[15] Padash. A., Nabavi. S., Dehzad. B., Jozi. S. and Moradi. N. (2010) Strategic Plan for Development of Environmental Conservation in Marine Protected Areas, Case Study: Mand Protected Area in Busherhr Province. Environmental Researches, 1, 53-66.

[16] Jafari, S., Yousefsakie, Y., Dozhkam, S., Alavian Petroudi, S., Yaghoubzadeh, M. and Danekar, A. (2013) Formulating Managerial Strategies for Protecting Miankale Wetland Using SWOT Analysis. Wetlands Eco-Biology, 16, 5-18.

[17] Baker, N.J. (2008) Sustainable Wetland Resource Utilization of Sango Bay through Eco-Tourism Development. African Journal of Environmental Science and Technology, 2, 326-335.

[18] Nouri, G. and Mehdinasab, M. (2010) Evaluation of the Ecological and Tourism Development Capabilities of Gahar Lake Using SWOT. Journal of Wetland, 5, 5766.

[19] Masoudi, M., Mahini, A., Mohammadzadeh, M., Mir Karimi, H. and Abdi, A. (2011) Assessment of Recreation Opportunities in Miankaleh Wildlife Refuge. Environment and Development, 3, 53-60.

[20] Paliwal, R. (2006) EIA Practice in India and Its Evaluation Using SWOT Analysis. Environmental Impact Assessment Review, 26, 492-510. https://doi.org/10.1016/j.eiar.2006.01.004

[21] Zarrabi, A., Alizadeh Asl, J. and Bahari, A. (2014) Analysis of Tourism Infrastructures in the Ecotourism Destination of Band, Uremia Using SWOT. Geography and planning, 48, 177-210.

[22] Ziaei, M. and Mirzaeoe, R. (2009) Managerial Challenges and Development of Tourism in Protected Areas of Khazar Sea Southern Coasts, Case Study: Miankaleh Wildlife Refuge. Tourism Studies Quarterly, 2, 1-34.

[23] Barati, F., Mirhosini, S.A. and Aghanajafi, S. (2014) Codification of Eco-Tourism Sustainable Development Strategic Plan in Protected Areas Benefit with a Combination of Techniques SWOT, IEM and QSPM (Case Study: Varjin Protected Area). 2nd Congress of Environment, Energy and Bio-Defense, Tehran, 15 September 2016, 1-15.

[24] Kajanus, M., Kangas, J. and Kurttila, M. (2004) The Use of Value Focused Thinking and the SWOT Hybrid Method in Tourism Management. Tourism Management, 25, 499-506. https://doi.org/10.1016/S0261-5177(03)00120-1

[25] Omrani, G., Karbasi, A., Arjmandi, R. and Habibpour, A. (2010) Formulating an Optimal Strategy for Management System of Rural Wastes Using SWOT and QSPM, Case Study: Rasht. Urban Management Quarterly, 26, 41-62.

[26] Karbasi, A., Monavvari, S. and Moghouee, R. (2007) Strategic Management of Environment. Kavosh Ghalam Publications, Tehran, Iran. 
[27] Nahman, A. and Godfrey, L. (2010) Economic Instruments for Solid Waste Management in South Africa: Opportunities and Constraints, Resources. Conservation and Recycling, 54, 521-531. https://doi.org/10.1016/j.resconrec.2009.10.009

[28] Chang, H. and Huang, W. (2006) Application of a Quantification SWOT Analytical Method. Mathematical and Computer Modeling, 43, 158-169.

https://doi.org/10.1016/j.mcm.2005.08.016

[29] Mohammadizadeh, M., Karbasi, A. and Sahebi, M. (2013) Environmental Management of Hashilan Wetland Using SWOT. Environment Quarterly, 57, 13-27.

Submit or recommend next manuscript to SCIRP and we will provide best service for you:

Accepting pre-submission inquiries through Email, Facebook, LinkedIn, Twitter, etc. A wide selection of journals (inclusive of 9 subjects, more than 200 journals)

Providing 24-hour high-quality service

User-friendly online submission system

Fair and swift peer-review system

Efficient typesetting and proofreading procedure

Display of the result of downloads and visits, as well as the number of cited articles

Maximum dissemination of your research work

Submit your manuscript at: http://papersubmission.scirp.org/

Or contact oje@scirp.org 